- Hoài sơn: Sắc ký đồ của dung dịch thử có các vết cùng giá trị $R_{f}$ và cùng màu sắc với các vết trên sắc ký đồ của dung dịch đối chiếu.

- Sơn thù: Dưới ánh sáng ban ngày, trên sắc ký đồ của dung dịch thử xuất hiện vết màu đỏ tím có cùng màu và giá trị $R_{f}$ với các vết trên sắc ký đồ của dung dịch đối chiếu. Dưới ánh sáng tử ngoại ở bước sóng 365 nm, trên sắc ký đồ của dung dịch thử xuất hiện vết có huỳnh quang màu vàng cam có cùng màu và giá trị $R_{f}$ với các vết trên sắc ký đồ của dung dịch đối chiếu.

Định lượng. Hàm lượng cao tan trong cồn $70^{\circ}$ là $121 \mathrm{mg} \pm 4,5 \%>100 \mathrm{mg}$ cao cho 1 viên nang (quy về $0 \%$ ẩm).

\section{BÀN LUẬN}

Với 6 thành phần dược liệu khác nhau, công thức bào chế của lục vị hoàn có sự phối hợp giữa cao chiết và bột dược liệu nhằm tối ưu lượng dược liệu sử dụng.

\section{KẾT LUÂNN}

- Đã xác định tỷ lệ dược liệu dùng nấu cao và xay bột phù hợp.

- Đã chế biến được cao dược liệu, bột mịn dược liệu.

- Xây dựng được công thức và bào chế viên nang lục vị hoàn.

- Kiểm nghiệm viên nang lục vị hoàn đạt yêu cầu về chất lượng của viên nang.

KIẾN NGH!
- Tối ưu hóa công thức bào chế viên nang lục vị hoàn.

- Tiêu chuẩn hóa nguyên liệu và thành phẩm dựa trên các phương pháp hiện đại.

- Nghiên cứu độc tính bất thường trên chuột và thử nghiệm lâm sàng.

- Nghiên cứu độ ổn định của chế phẩm.

- Tiến hành sản xuất ở quy mô pilot.

\section{TÀI LIỆU THAM KHẢO}

1. Bộ Y tế (2018). Danh mục thuốc thiết yếu.

2. Hải Thượng $Y$ Tông Tâm Lĩnh, Lê Hữu Trác, Hải Thượng Lãn Ong, Nhà xuất bản $Y$ học, 2008, $1-17$.

3. Lee HyunKyung, Cha Hwa Jun Cha, Poria cocos. Wolf extracts represses pigmentation in vitro and in vivo, Cellular and molecular biology 64 (5), 2018, $80-84$.

4. Huang Jun, Zhang Yiwei, Gao Qinghan, Yin Lei, Quan Hongfeng, Chen Rong, Fu Xueyan, Lin Dingbo, Ethnopharmacology, phytochemistry, and pharmacology of Cornus officinalis Sieb. et Zucc, Journal of Ethnopharmacology, Vol 213, $2018,280-301$.

5. Liu S, Li Y, Yi F, Liu Q, Chen N, He X, He C, Xiao P. Resveratrol oligomers from Paeonia suffruticosa protect mice against cognitive dysfunction by regulating cholinergic, antioxidant and anti-inflammatory pathways. Journal of Ethnopharmacol, Vol 260, 2020.

6. Jin $Q$, Zhang J, Hou J, Lei $M$, Liu $C$, Wang $X$, Huang $Y$, Yao S, Hwang BY, Wu W, Guo D. Novel $\mathrm{C}-17$ spirost protostane-type triterpenoids from Alisma plantago-aquatica with antiinflammatory activity in Caco-2 cells. Acta Pharmaceutica Sinica B. 9(4), 2019, $809-818$.

\title{
TIẾN TRIỂN CỦA TỔN THƯƠ'NG THÂ̂N CẤP Ở BỆNH NHÂN NGộ ĐộC CẤP TẠI TRUNG TÂM CHỐNG ĐộC, BỆNH VIỆN BẠCH MAI
}

\section{TÓM TẮT}

Mục tiêu: Đánh giá tiến triển của tổn thương thận cấp và một số yếu tố liên quan ở bệnh nhân ngộ độc cấp". Đối tượng và phương pháp: Nghiên cứu mồ tả tiến cứu trên 73 bệnh nhân ngộ độc cấp có tổn thương thận cấp điêu trị tại Trung tâm Chống độc, bênh viện Bạch Mai từ tháng 7/2019 đến 7/2020. Các biến số nghiên cứu được thu thập theo mâuu bệnh án thống nhất, tổn thương thận cấp được chẩn đoán khi khi creatinin máu $\geq 130 \mu \mathrm{mol} / / \mathrm{l}$ và được chia ra 3 mức

*Trung Tâm Chống Độc - Bệnh viện Bạch Mai Chịu trách nhiệm chính: Đặng Thị Xuân Email: xuandangthi17@gmail.com Ngày nhận bài: 4.01.2021 Ngày phản biện khoa học: 2.3.2021 Ngày duyệt bài: 15.3.2021

\section{Đặng Thị Xuân*}

độ nặng theo KDIGO. Kết quả: Tỉ lệ bệnh nhân có tổn thương thân tại thời điểm nhập viện mức độ 1 là $24,7 \%$, mức độ 3 là $17,8 \%$ và thấp nhất là mức độ 2 là $9,6 \% ; 47,9 \%$ bệnh nhân chưa có tổn thương. Có 60,3\% bệnh nhân có tổn thương thận nặng lên trong quá trình điều trị. $60,3 \%$ bệnh nhần có chức năng thận hồi phục khi ra viện, tỉ lệ hồi phục cao nhất là nhóm tổn thương thận mức độ 1 khi vào viện (100\%). Ngộ độc càng nặng (theo thang điểm PSS) thì tỉ lệ tôn thương thận càng nặng. Bệnh nhân sống có tỉ lệ thận hồi phục cao hơn so với nhóm tử vong. Kết luận: Mức độ nặng tổn thương thận lúc vào viện ít liên quan với mức độ nặng của tôn thương thận trong quá trình điều trị và tiên lượng hồi phục chức năng thận.

Tư khóa: Ngộ độc cấp, tổn thương thận cấp.

\section{SUMMARY}

EVOLUTION OF ACUTE KIDNEY INUURY IN

PATIENTS WITH ACUTE POISONING AT POISON 


\section{CONTROL CENTER, BACH MAI HOSPITAL}

Objective: aimed to investigate the progression of acute kidney injury and some related factors in patients with acute poisoning at the Poison Control Center, Bach Mai Hospital. Subjects and Methods: A cross-sectional, prospective study on 73 acute poisoning patients with acute kidney injury at the Poison Control Center, Bach Mai Hospital was conducted from July 2019 to $7 / 2020$. The study variables were collected according to consistent medical records, acute kidney injury was diagnosed when blood creatinine level $\geq 130 \mu \mathrm{mol} / \mathrm{l}$ and divided into 3 severity according to KDIGO. Results: The time of admission, the proportion of patients with level 1 of kidney injury was $24.7 \%$; level 3 was $17.8 \%$ and the lowest was level $2(9.6 \%) ; 47.9 \%$ of patients have no acute kidney injury. There are $60.3 \%$ of patients with kidney injury progresses up during treatment. $60.3 \%$ of patients with renal function recovered upon discharge from the hospital, the highest recovery rate was in the first level group of kidney damage at hospital admission (100\%). The more severe the poisoning (on a PSS scale), the more severe the incidence of kidney injury. Living patients had a higher rate of kidney recovery compared to the death group. Conlusion: the severity of kidney damage at admission was less correlated with the severity of kidney damage during treatment and the prognosis of renal recovery.

Keywords; Acute poisoning, acute kidney injury.

\section{I. ĐĂT VẤN ĐỀ}

Tổn thương thận cấp là tình trạng giảm chức năng thân đôt ngột và kéo dài trong vài giờ hoặc vài ngày, dẩn đển giảm mức lọc cầu thân, ứ đọng các sản phẩm chuyển hóa. Thận rất dễ bị tổn thương trong ngộ độc cấp, do sự tập trung cao nồng độ độc tố trong tổ chức kẽ, tuỷ thận và ở tế bào biểu mô ống thận. Một số sản phẩm chuyển hóa thứ phát sản sinh sau ngộ độc cấp cũng gây độc cho nhu mô thận.

Tổn thương thận cấp (AKI) chiếm 35\%-65\% bệnh nhân hồi sức chống độc và $5 \%-26 \%$ bệnh nhân vào viện. Nhiều nghiên cứu cho thấy tî̉ lệ tử vong ở bệnh nhân có tổn thương thận cấp tăng gấp 3 - 4 lần so với bênh nhân khồng có tổn thương thận cấp. Hơn nữa, sự gia tăng mức độ nặng của tổn thương thận cấp liên quan với gia tắng nguy cơ tử vong, bệnh nhân tổn thương thận cấp càng nặng thì nguy cơ tử vòng càng nhiều. Tỉ lệ tử vong tại bệnh viện ở những bệnh nhân tại khoa hồi sức chống độc có tổn thương thận cấp từ $9 \%$ - $26 \%$ tùy giai đoạn tổn thương so với 6 \% bệnh nhân không có tổn thương thận cấp [2],[3].

Các tác nhân ngộ độc có thể gây tổn thương thận cấp theo các cơ chế khác nhau. Những tổn thương do hoại tử ống thận có thể kéo dài vài tuần nhưng có khả năng hồi phục hoàn toàn, tuy nhiên có những bệnh nhân suy thân tử vong nhanh trong tình trạng suy đa tạng. Ở Việt nam, còn ít nghiên cứu về tổn thương và diễn tiến của bênh nhân tổn thương thận trong ngộ độc. Nhằm nâng cao hiệu quả điều trị và tiên lượng cho các bệnh nhân ngộ độc đặc biệt là các bệnh nhân có tổn thương thận cấp, chúng tôi tiến hành nghiên cứu này với mục tiêu: đánh giá tiến triển tổn thương thận cấp và một số yếu tố liên quan ở bệnh nhân ngộ độc cấp điều trị tại Trung tâm Chống độc, bệnh viện Bạch Mai.

\section{II. ĐỐI TƯƠNG VÀ PHƯƠNG PHÁP NGHIÊN CỨU}

2.1. Đối tượng nghiên cứu. Các bệnh nhân ngộ độc cấp có tổn thương thận cấp tại Trung tâm Chống Độc - Bệnh viện Bạch Mai từ tháng 7/2019 đến 7/2020:

Bệnh nhân được chẩn đoán ngộ độc cấp khi có $\geq 2 / 3$ tiêu chuẩn sau [1]: (1) tiếp xúc với độc chất, (2) có biểu hiện lâm sàng của ngộ độc, (3) xét nghiệm thấy chẩt độc trong dịch dạ dày, nước tiểu, máu. Bệnh nhân được chẩn đoán tổn thương thận cấp khi creatinin máu $\geq 130 \mu \mathrm{mol} / \mathrm{l}$ [7].

- Tiêu chuẩn loại trừ: bệnh nhân có bệnh thận mạn (tiền sử có bệnh thận tiết niệu, suy thận từ trước, thiếu máu tương ứng với mức đô suy thận mạn, hai thận kích thước nhỏ hoặc không đều trên siêu âm) hoặc mới phẫu thuật thận và tiết niệu. Bệnh nhân nằm viện ngắn hởn 2 ngày, không đủ số liệu theo dõi. Bệnh nhân trong tình trạng có ngừng tuần hoàn, chết não khi nhập viện.

\subsection{Phương pháp nghiên cứu}

- Thiết kế nghiên cứu: mô tả tiến cứu, phương pháp chọn mẫu toàn bộ tất cả các bệnh nhân ngộ độc cấp có tổn thương thận cấp (ngay từ khi nhập viện và hoặc trong quá trình điều trị) điều trị tại Trung tâm Chống độc Bệnh viện Bạch Mai trong thời gian nghiên cứu.

- Các biến số nghiên cứu

- Đặc điểm chung: tuổi, giới, nguyên nhân ngộ độc (tai nạn, tự tử).

- Tî̉ lệ tử vong ở bệnh nhân ngộ độc cấp có tổn thương thận cấp.

- Thời gian nằm viện.

- Chẩn đoán tổn thương thận cấp: khi creatinin máu $\geq 130 \mu \mathrm{mol} / \mathrm{l}$.

- Đánh giá mức độ tổn thương thận áp dụng dựa theo KDIGO [3]:

+ Chức năng thận bình thường: creatinin < $130 \mu \mathrm{mol} / \mathrm{l}$.

+ Mức độ 1: creatinin máu từ 130 - 170 mol/l. + Mức độ 2: creatinin máu từ 171 - 259 umol/l. + Mức độ 3: creatinin máu $\geq 260$ mol/l. 
Nghiên cứu lấy theo giá trị creatinin nền bình thường $1 \mathrm{mg} / \mathrm{dl}$, tổn thương thận cấp khi creatinin máu tăng lên $1,5 \mathrm{mg} / \mathrm{dl}$ tương ứng $\geq 130 \mu \mathrm{mol} / \mathrm{l}$ [4]. Trong nghiên cứu chúng tôi không sử dụng tiêu chuẩn số lượng nước tiểu chẩn đoán tổn thương thận cấp, do có nhiều yếu tố làm kết quả không chính xác như bệnh nhân đã sử dụng thuốc tăng bài niệu (furosemide...).

- Đánh giá tiến triển của các mức độ tổn thương thận cấp ở bệnh nhân ngộ độc cấp:

+ Tổn thương thận tăng lên: khi nồng độ creatinin máu theo dõi trong quá trình điều trị cao hơn so với thời điểm vào viện.

+ Bệnh nhân hồi phục chức năng thận: creatinin máu về bình thường.

- Chẩn đoán mức độ nặng của ngộ độc dựa vào bảng điểm PSS (Poisoning Severity Score)[5].

+ Không ngộ độc (độ 0): không có triệu chứng của ngộ độc.

+ Nhe (độ 1): nhẹ, thoáng qua, các triệu chứng có thể tự hồi phục.

+ Trung bình (độ 2): triệu chứng rõ hoặc kéo dài.

+ Nặng (độ 3): triệu chứng nặng, đe doạ đến tính mạng.

+ Tử vong (độ 4): nguy kịch, tử vong.

- Suy đa tạng: suy $\geq 2$ tạng

- Phương pháp thu thập số liệu: đánh giá các chỉ tiêu nghiên cứu theo mẩu bệnh án nghiên cứu thống nhất.

2.3. Xử lý số liệu: Số liệu được xử lý và phân tích bằng phần mềm thống kê $y$ học SPSS 22.0. Biến định tính: tính tỉ lệ phần trăm, so sánh tỉ lệ bằng test $x 2$. Biến định lượng: tính trung bình và độ lệch chuẩn, so sánh giữa các nhóm bằng t-test Śtudent, kết quả nghiên cứu trình bày dưới dạng trung bình \pm độ lệch chuẩn (mean $\pm \mathrm{SD}$ ). Khác biệt có ý nghĩa thổng kê khi $\mathrm{p}<0,05$.

\section{KẾT QUẢ NGHIÊN CỨU}

3.1. Đặc điểm chung. Trong số 73 bệnh nhân nghiên cứu, tuổi trung bình là $44 \pm 16,7$; nhóm tuổi từ 35-44 chiếm tỷ lệ cao nhất: $26,0 \%$. Tỷ lệ nam/nữ là $3 / 1$. Nguyên nhân ngộ độc chủ yếu bệnh nhân có hành vi tự tử chiếm $68,5 \%$, tai nạn $31,5 \%$. Tỉ lệ tử vong của bệnh nhân ngộ độc cấp có tổn thương thận cấp là 22/73 BN (30,1\%).

\subsection{Tiến triển của tổn thương thận cấp ở bệnh nhân ngộ độc cấp}

Bảng 1: Mức độ nặng của tổn thương thận cấp khi nhập viện

\begin{tabular}{|c|c|c|c|c|}
\hline \multirow{2}{*}{ Mức độ tổn thương thận } & \multicolumn{2}{|c|}{ Khi nhập viện } & \multicolumn{2}{c|}{$\begin{array}{c}\text { Số BN tốn thương thân tăng } \\
\text { lền trong quá trinh điều trị }\end{array}$} \\
\cline { 2 - 5 } & Số BN(n) & Tỷ lệ(\%) & Số BN(n) & Tỳ lệ(\%) \\
\hline Chưa có tốn thương thận & 35 & 47,9 & 35 & 100 \\
\hline Mức độ 1 & 18 & 24,7 & 5 & 27,8 \\
\hline Mức độ̀ 2 & 7 & 9,6 & 2 & 28,6 \\
\hline Mức độ̣ 3 & 13 & 17,8 & 2 & 15,4 \\
\hline Tống & $\mathbf{7 3}$ & $\mathbf{1 0 0}$ & $\mathbf{4 4}$ & $\mathbf{6 0 , 3}$ \\
\hline
\end{tabular}

Nhận xét: Tỉ lệ bênh nhân chưa có tốn thương thận cấp tại thời điếm mới nhập viện chiếm cao nhất $47,9 \%$. Tỉ lệ bệnh nhân có tổn thương thận tại thời điểm nhập viện mức độ 1 là $24,7 \%$, mức độ 3 là $17,8 \%$ và thấp nhất là mức độ 2 là $9,6 \%$.

Có 60,3\% bệnh nhân nghiên cứu có tổn thương thận nặng lên trong quá trình điều trị. Trong đó, $100 \%$ bệnh nhẩn lúc nhập viện chưa có tổn thương thận sau đó đều có tiến triển tổn thương thận nặng lên, tiếp đến nhóm mức độ 2 (28,6\% tiến triển nặng lên), mức độ 1 (27,8\% tiến triển nặng lên) và ít nhất là mức độ 3 (15,4\% tiến triển nặng lên).

Bảng 2: Mức độ tồn thương thận tại thời điểm ra viện

\begin{tabular}{|c|c|c|c|c|c|}
\hline \multirow{2}{*}{$\begin{array}{l}\text { Mức độ tổn thương thận } \\
\text { khi nhập viện }\end{array}$} & \multicolumn{4}{|c|}{ Mức độ tổn thương thận khi ra viện } & \multirow[b]{2}{*}{$\mathbf{p}$} \\
\hline & Hồi phục & Mức độ 1 & Mức độ 2 & Mức độ 3 & \\
\hline Chưa có tổn thương $(\mathrm{n}=35)$ & $17(48,6 \%)$ & $6(17,1 \%)$ & $6(17,1 \%)$ & $6(17,1 \%)$ & \\
\hline Mức độ $1(n=18)$ & $18(100 \%)$ & 0 & 0 & 0 & \\
\hline Mức độ $2(n=7)$ & $1(14,2 \%)$ & $2(28,6 \%)$ & $2(28,6 \%)$ & $2(28,6 \%)$ & \\
\hline Mức độ $3(n=13)$ & $8(61,5 \%)$ & $1(7,7 \%)$ & $1(7,7 \%)$ & $3(23,1 \%)$ & $<0,05$ \\
\hline Tổng & $44(60,3 \%)$ & $9(12,3 \%)$ & $9(12,3 \%)$ & $11(15,1 \%)$ & $73(100 \%)$ \\
\hline
\end{tabular}

Nhận xét: Nghiên cứu ghi nhận có 44/73 (chiếm 60,3\%) bệnh nhân nghiên cứu có chức năng thận hồi phục khi ra viện. Tî lệ hồi phục cao nhất là nhóm tổn thương thận mức độ 1 khi vào viện $(100 \%)$, mức độ 3 hồi phục $(61,5 \%)$, nhóm tổn thương thận xuất hiện mới trong quá trình điều trị viện có tỉ lệ hồi phục là 48,6\%, mức độ 2 có tỉ lệ hồi phục thấp nhất là $14,2 \%$. 
Bảng 3: Liên quan giữa mức độ tổn thương thận và mức độ nặng của ngộ độc

\begin{tabular}{|c|c|c|c|c|c|c|}
\hline \multicolumn{2}{|c|}{ Đặc điểm } & $\begin{array}{c}\text { Chung } \\
(\mathrm{n}=73 \mathrm{BN})\end{array}$ & $\begin{array}{l}\text { Mức độ } 1 \\
(n=24 B N)\end{array}$ & $\begin{array}{l}\text { Mức độ } 2 \\
(\mathrm{n}=14 \mathrm{BN})\end{array}$ & $\begin{array}{l}\text { Mức độ } 3 \\
(\mathrm{n}=35 \mathrm{~B} N)\end{array}$ & $\mathbf{p}$ \\
\hline \multicolumn{2}{|c|}{ Tụt huyết áp $(n, \%)$} & $34(46,6 \%)$ & $11(45,8 \%)$ & $8(57,1 \%)$ & $15(42,9 \%)$ & $\overline{05}$ \\
\hline \multirow{3}{*}{ PSS } & Nhe & $18(2$ & $12(50 \%)$ & $3(21,4 \%)$ & $3(8,6 \%)$ & \multirow{3}{*}{$<0,05$} \\
\hline & Trung bình & $23(31,5 \%)$ & $8(33,3 \%)$ & $8(57,2 \%)$ & $7(20 \%)$ & \\
\hline & Nặng & $32(43,8 \%)$ & $4(16,7 \%)$ & $3(21,4 \%)$ & $25(71,4 \%)$ & \\
\hline \multicolumn{2}{|c|}{ Thời gian nằm viện (ngày) } & $6(3,11)$ & $4(3,7)$ & $4,5(2,9)$ & $8(6,12)$ & $<0,05$ \\
\hline \multicolumn{2}{|c|}{ Suy đa tạng $(n, \%)$} & 44( & $7 \%)$ & $3 \%)$ & $19(54,3 \%)$ & $>0,05$ \\
\hline \multicolumn{2}{|c|}{ Tứ vong $(n, \%)$} & $22(30,1 \%)$ & $7(29,1 \%)$ & $8(57,1 \%)$ & $7(20 \%)$ & $<0,05$ \\
\hline
\end{tabular}

Nhận xét: Ngộ độ càng nặng (theo thang điểm PSS) thì có tỉ lệ tốn thương thận nặng cao hơn có ý nghĩa thống kê $(p<0,05)$. Tổn thương thận mức độ 1 có ngày nằm viện thấp nhất ( 4 ngày), mức độ 2 ( 4,5 ngày), nằm viện dài ngày nhất là tổn thương thận mức độ 3 (8 ngày), $p<0,05$. Tî lệ tử vong cao nhất mức độ $2(57,1 \%)$; mức độ $1(29,1 \%)$, mức độ $3(20 \%), p<0,05$.

Bảng 4: Một số đặc điểm ở bệnh nhân sông và tử vong

\begin{tabular}{|c|c|c|c|c|}
\hline \multicolumn{2}{|c|}{ Đặc điểm } & Sống ( $n=51 B N)$ & Tứ vong $(n=22 B N)$ & $\mathbf{p}$ \\
\hline \multicolumn{2}{|c|}{ Tuổi (năm) } & $43 \pm 16,9$ & $48 \pm 15,6$ & $>0,05$ \\
\hline \multirow{3}{*}{ PSS } & Nhe & $17(33,3 \%)$ & $1(4,6 \%)$ & \multirow{3}{*}{$<0,05$} \\
\hline & Trung bình & $14(27,5 \%)$ & $9(40,9 \%)$ & \\
\hline & Nặng & $20(39,2 \%)$ & $12(54,6 \%)$ & \\
\hline \multicolumn{2}{|c|}{ Ngày nằm viện } & $7(4,12)$ & $5,5(2,8)$ & $>0,05$ \\
\hline \multicolumn{2}{|c|}{ Tụt huyết áp } & $16(31 \%)$ & $18(82 \%)$ & $<0,05$ \\
\hline \multirow{2}{*}{\multicolumn{2}{|c|}{ Suy đa tạng }} & $31(42,5 \%)$ & $13(59,1 \%)$ & $>0,05$ \\
\hline & & $25(49,0 \%)$ & $11(50 \%)$ & $>0,05$ \\
\hline \multicolumn{2}{|c|}{ Thận hồi phục } & $37(73 \%)$ & $7(32 \%)$ & $<0,05$ \\
\hline
\end{tabular}

Nhận xét: Nhóm bệnh nhân tử vong có tỉ lệ có triệu chứng ngộ độc nặng (PSS), tỉ lệ tụt huyết áp và tỉ lệ thận không hồi phục cao hơn có ý nghĩa thống kê so với nhóm bệnh nhân sống $(p<0,05)$.

\section{BÀN LUÂN}

Nghiên cứu ghi nhận thời điểm vào viện, tỉ lệ bênh nhân chưa tổn thương thân cao nhất 35/73 bệnh nhân $(47,9 \%)$ tiếp đến là tổn thương thận mức độ 1 có $18 / 73$ bệnh nhân (24,7\%), mức độ 3 có $13 / 73$ bệnh nhân $(17,8 \%)$ và thấp nhất là mức độ 2 có $7 / 73$ bệnh nhân $(9,6 \%)$. Trong nghiên cứu tổn thương thận cấp xuất hiện những ngày sau khi vào viện là $48 \%$ đây là đối tượng cần theo dõi đánh giá sát để tránh bỏ sót tổn thương và có thái độ dự phòng cũng như điều trị kịp thời nhằm hạn chế độ nặng, tai biến, biến chứng của tổn thưởng thận cấp nói riêng và cải thiên kết quả điều tri nói chung. Tổn thương thận muôn có thể là thứ phát sau thiếu máu tạng, nhiễm trùng, nhưng cũng gặp nhiều ở ngộ độc các chất độc gây thổn thương thận muộn như paraquat, colchicin...

Trong nghiên cứu của chúng tôi 44/74 bệnh nhân $(60,3 \%)$ tổn thương thận tăng lên sau khi vào viện bao gồm: nhóm tổn thương thận xuất hiện sau khi vào viện sẽ tiến triển thành tổn thương thận cấp ở các mức độ nặng khác nhau trong quá trình nằm viện điều trị $(100 \%)$, tổn thương mức độ 1 khi vào viện có $5 / 18$ bệnh nhân $(27,8 \%)$ tổn thương tăng lên, tổn thươning mức độ 2 khi vào viện có $2 / 7$ bệnh nhân $(28,6 \%)$ tổn thương tăng lên, tổn thương tăng lên ít nhất trong quá trình nằm viện điều trị là nhóm tổn thương mức độ 3 lúc vào viện có $2 / 13$ bệnh nhân $(15,4 \%)$. Kết quả gợi ý không thể thông qua mức độ nặng nặng thời điểm vào viện để dự đoán và tiên lượng mức độ nặng tổn thương thận trong quá trình điều trị.

Có $60,3 \%$ bệnh nhân hồi phục thận tại thời điểm ra viện. Tỉ lệ hồi phục cao nhất là tổn thương mức độ 1 khi vào viện có $18 / 18$ bệnh nhân $(100 \%)$, nhóm bệnh nhân tiến triển tổn thương trong khi nằm viện có tỉ lệ hồi phục khi ra viện là $48,6 \%$. Kết quả này gợi ý mức độ nặng tổn thương thận lúc vào viện ít có giá trị dự đoán tiên lượng tình trạng hồi phục thận thời điểm ra viện.

Theo phân độ mức độ nặng của ngộ độc theo thang điểm PSS, bệnh nhân nghiên cứu chia làm 3 nhóm ngộ độc nhẹ, trung bình và nặng. Ở các nhóm khác nhau tổn thương thận cấp khác nhau, mức độ ngộ độc nhẹ có tổn thương thận nhẹ hơn có ý nghĩa thống kê so với ngộ độc trung bình và nặng theo PSS. Kết quả này gợi ý đánh giá tiên lượng tổn thương thận cấp của bệnh nhân ngộ độc cấp trong quá trình điều trị 
tại bệnh viện thông qua mức độ nặng của ngộ độc.

Tương tự, tổn thương thương thận mức độ 1 có số ngày nằm viện trung bình thấp nhất ( 4 ngày), mức độ 2 ( 4,5 ngày), mức độ 3 ( 8 ngày) với $\mathrm{p}<0,05$. Tỉ lệ tử vong cao nhất mức độ 2 $(57,1 \%)$ mức độ $1(29,1 \%)$, mức độ $3(20 \%)$, $\mathrm{p}<0,05$. Tổn thương thận trong quá trình điều trị càng nặng thì ngày nằm viện càng dài. Kết quả nghiên cứu của Negi $S$. và cộng sự về đặc điểm dịch tễ tổn thương thận cấp nói chung thì mức độ tổn thương thận có liên quan với tỉ lệ tử vong, ngày nằm viện và chỉ định điều trị thay thế thận [4]. Khác với Negi S. tỉ lệ tử vong trong nghiên cứu của tôi ít liên quan với độ nặng tổn thương thận, có thể do đặc điểm nhóm bệnh nhân nghiền cứu là ngộ độc khác với nghiên cứu của Negi S. nghiên cứu bệnh nhân nằm viện có tổn thương thận nói chung.

Theo mức độ nặng của ngộ độc (PSS) nhóm bệnh nhân có triệu chứng ngộ độc nặng có tỉ lệ tử vong $54,6 \%$ cao hơn tỉ lệ tử vong nhóm ngố độc mức độ trung bình 40,9\% và mức độ nhe tử vong $4,6 \%(p<0,05)$. Nêu độ nặng tổn thương thận không có mối liên quan với tỉ lệ tử vong thì ở đây mức độ nặng của ngộ độc có liên quan với tỉ lệ tử vong. Bệnh nhân tử vong do tác động trực tiếp của chất độc lên chức phận sống (ngộ độc paraquat gây xớ hóa phổi, tổn thương thần kinh trung ương trong ngộ độc methanol, suy đa tạng do ngộ độc ma túy đá...), tử vong cũng có thể do biến chứng viêm phổi, nhiểm khuẩn huyêt, rối loạn đông máu trong điều trị những ngộ độc nặng nằm viện thở máy kéo dài.

Nhóm bệnh nhân sống có tỉ lệ hồi phục thận $(72,5 \%)$ cao hơn nhóm tử vong $(31,8 \%)$, $\mathrm{p}<0,05$. Kết quả này cũng tương tự nghiên cứu của Singbartl K. và J.A. Kellum chỉ ra trong nghiên cứu tổn thương thận cấp ở bệnh nhân nặng, kết cục ở bệnh nhân có tổn thương thận cấp phụ thuộc vào bệnh lí nền, mức độ nặng và thời gian tổn thương thận, tình trạng nền của bênh nhân [6].

\section{KẾT LUÂN}

Đa số bệnh nhân $(60,3 \%)$ có tổn thương thận nặng lên trong quá trình điều trị, đặc biệt là các bệnh nhân chưa có tổn thương thận tại thời điểm nhập viện. $60,3 \%$ bệnh nhân có hồi phục chức năng thận khi ra viện, trong đó tỉ lệ hồi phục cao nhất là nhóm tổn thương thận mức độ 1 khi nhập viện. Ngộ độc càng nặng (theo thang điểm PSS) thì tỉ lệ tổn thương thận càng nặng. Bệnh nhân sống có tỉ lệ thận hồi phục cao hơn so với nhóm tử vong.

Tỉ lệ tử vong của bệnh nhân ngộ độc cấp có tổn thương thận cấp là 30,1\%.

\section{TÀI LIÊU THAM KHẢO}

1. Nguyễn Thị Dụ. Định hướng chung chẩn đoán và xứ trí ngộ độc cấp. Tư vấn chẩn đoán và xử trí nhanh ngộ độ́c câp. Nhà xuất bản Y học; 2004.

2. De Mendonça A, Vincent J-L, Suter P. Acute renal failure in the ICU: risk factors and outcome evaluated by the SOFA score. Intensive Care Medicine. 2000;26(7):915-921.

3. Kellum JA, Lamerie N, Aspelin P. KDIGO Clinical practice guidline for acute kidney injury. Kidney internatinal supplement. 2012:1-138.

4. Negi S, Koreeda D, Kobayashi S. Acute kidney injury: Epidemiology, outcomes, complications, and therapeutic strategies. Seminars in dialysis. 2018;31(5):519-527.

5. Persson HE, Sjoberg GK, Hainers JA, Pronczuk de Garbino J. Poisoning severity score. Grading of acute poisoning. J Toxicol Clin Toxicol. 1998;36(3):205-213.

6. Singbartl $K$, Kellum JA. AKI in the ICU: definition, epidemiology, risk stratification, and outcomes. Kidney international. 2012;81(9):819-825.

7. Thadhani R, Pascual M, Bonventre jV. Acute renal failure. The New England journal of medicine. 1996;334(22):1448-1460.

\section{KẾT QUẢ ĐÎ̂̀U TRI PHẪU THUÂ̂T BẮC CẦU ĐộNG MẠCH TRONG VÀ NGOÀI SỌ TRONG PHÌNH ĐộNG MẠCH NÃO PHỨC TẠP}

\section{TÓM TẮT}

\footnotetext{
*Bệnh viện Việt Đức

Chịu trách nhiệm chính: Ngô Mạnh Hùng

Email: ngomanhhung2000@gmail.com

Ngày nhận bài: 5.01.2021

Ngày phản biện khoa học: 3.3.2021

Ngày duyệt bài: 16.3.2021
}

\section{Ngô Mạnh Hùng*}

Mục tiêu: (1) mô tả các phương pháp điều trị phẫu thuật phình động mạch não phức tạp; (2) đánh giá kết quả điều trị phình động mạch não phức tạp và khổng lồ. Đối tượng và phướng pháp nghiên cứu: Nghiến cứu hồi cứu 17 bệnh nhân đã được điều trị phẫu thuật bắc cầu động mạch trong và ngoài sọ trong điều trị phình động mach não khổng lồ tại bệnh viện Việt Đức. Kết quả: tuổi trung bình: 37,39 $\pm 12,67$; có $58,83 \%$ nữ; các triệu chứng bao gồm: đau đầu, vắng ý thức, thất ngôn, yếu liệt vạn động, co 